\title{
Distribution and retention of larval fishes near reefs in the Gulf of California
}

\author{
Michael W. Brogan* \\ Department of Ecology and Evolutionary Biology, University of Arizona, Tucson, Arizona 85721, USA
}

\begin{abstract}
I conducted a study of larval fishes in the Gulf of Califormia, Mexico, with 3 objectives: identify the families that utilize the near-reef habitat throughout development; evaluate distributions of reef fishes for evidence of larval retention; and relate larval distributions of reef fishes to egg type and morphology of hatchlings. Analyses were based on 165 light-trap and plankton-net samples collected $\sim 1,20$, and $100 \mathrm{~m}$ off reefs during the summers of 1989 and 1990, and on previous offshore surveys. Sixteen families accounted for $>93 \%$ of all larvae collected near reefs, and only these families were considered further. At least 11 families, including epipelagic, sandy-bottom, and reef fishes, appeared to utilize the near-reef habitat throughout development. In addition, larval retention may have occurred in at least 5 of the reef fish families (Bythitidae, Chaenopsidae, Gobiesocidae, Labrisomidae, Tripterygiidae). Evidence for this included the presence of all larval size classes over reefs, high concentrations of larvae at $1 \mathrm{~m}$ and/or $20 \mathrm{~m}$ stations that decreased by 72.0 to $99.9 \%$ at $100 \mathrm{~m}$ stations, and absence or rarity in offshore surveys. Larvae of some gobiids may also have been retained, but distributions varied within the family. Larvae of other reef fish families (Balistidae, Blenniidae, Pomacentridae, and perhaps Haemulidae) appeared to disperse away from reefs. All families with evidence of retention spawned non-pelagic eggs and had well-developed hatchlings, but the reverse was not true. This suggests that these traits provide the opportunity for retention, but other taxon-specific factors determine whether such a distribution is realized.
\end{abstract}

KEY WORDS: Fish larvae - Distribution Retention - Rocky reefs - Reef fishes - Gulf of California

\section{INTRODUCTION}

The prevalence of pelagic young in tropical reef fishes is well established (Leis \& Rennis 1983, Thresher 1984, Leis \& Trnski 1989), but little is known about where most species spend their pelagic period (Leis 1991). The larvae of many species have been collected in open water, some at great distances from shore (Ahlstrom 1971, 1972, Leis 1983, Richards 1984, Young et al. 1986, Leis \& Goldman 1987, Victor 1987, Clarke 1991). This has led several authors to hypothesize advantages for offshore dispersal (e.g. Johannes 1978, Barlow 1981, Doherty et al. 1985). Little evidence has been offered to support these hypotheses, but the idea that larvae should develop offshore rather than near reefs is pervasive. For example, many aspects of

- Present address: School of Fisheries HF-15, University of Washington, Seattle, Washington 98195, USA spawning behavior are routinely interpreted as mechanisms to maximize the flushing of eggs and larvae off reefs (e.g. Johannes 1978, Doherty 1983, Ross 1983, Thresher 1984, Hunt von Herbing \& Hunte 1991), even though there are alternative explanations (Colin \& Clavijo 1988, Shapiro et al. 1988, Robertson 1991).

There might be advantages to offshore dispersal, but it also presents the problem of return transport once pelagic young reach the settlement stage. Although a variety of hydrographic mechanisms may aid the return of settlers (Norcross \& Shaw 1984, Lobel \& Robinson 1986, 1988, Kingsford \& Choat 1986, Shanks 1988, Kingsford 1990, Kingsford et al. 1991, Pineda 1991), considerable variation in their availability and effectiveness should be expected. If appropriate transport is lacking, potential settlers could be lost offshore through expatriation.

Expatriation could be minimized by the retention of pelagic stages near reefs throughout development. 
The relative benefit (or detriment) of such a distribution can be described in terms of mortality rates before and after larvae become competent to settle. Precompetent mortality will vary with the distributions of predators and prey, and there may or may not be a predictable relationship with distance from reefs (there are no data). However, once competence is attained, larvae near reefs should be able to settle quickly, while offshore larvae will have to delay settlement and suffer additional mortality until reefs are encountered. A decrease in length of the post-competent pelagic period and a greater encounter rate of competent larvae with suitable settlement habitat could favor larval retention, even if precompetent mortality is higher near reefs than offshore (within limits).

Nevertheless, constraints imposed by patterns of spawning and larval development could preclude retention in many species. For example, the eggs and young larvae of pelagic spawners drift passively with the currents. Older larvae may be capable swimmers, but by then substantial drift away from reefs may have already occurred. In contrast, non-pelagic spawners (live-bearers, brooders, and demersal spawners) keep their embryos on the reef, and hatching or birth is delayed in many species until the young have reached a comparatively large size (Thresher 1984). On average, larger larvae have better-developed sensory systems and swimming abilities (Blaxter 1986, Miller et al. 1988). This suggests that retention is most likely among non-pelagic spawners, especially those with large, well-developed hatchlings. Of course, favorable hydrographic conditions could lead to retention without the behavioral input of larvae (Black et al. 1991, Black 1993).

What evidence is there for retention in reef fishes? Marliave (1986) and Kingsford \& Choat (1989) found that larvae of several demersal spawners were concentrated within $100 \mathrm{~m}$ (or less) of temperate rocky reefs. All larval size classes appeared to be present there, and these taxa were rare or absent farther offshore. These observations are consistent with larval retention. Powles (1977) collected a wide size range of larval Jenkensia sp. (egg type unknown) over Barbados reefs, but none were taken in collections 1.8 to $26 \mathrm{~km}$ offshore. Leis $(1982,1986 a, 1991)$ and Leis \& Goldman $(1984,1987)$ suggested that a few species from several families (non-pelagic spawners, with few exceptions) might be retained within a few hundred meters to a few kilometers of Pacific coral reefs. Kobayashi (1989) found that postflexion larvae of a gobiid (demersal eggs) used vision to remain near a Hawaiian reef, but young larvae were dispersed away from the reef in open water. The rarity of studies from near reefs and the mixed nature of their results highlights the need for more work
In this paper I describe a study of larval fish distributions from the Gulf of California, Mexico. I focused on the extreme nearshore zone, using a light trap and a plankton net to sample larval fishes at 0 to $100 \mathrm{~m}$ from rocky reefs. The water immediately adjacent to reefs was of special interest because it may provide lowvelocity boundary layers and/or sensory cues that enable or enhance larval retention. These collections were the basis for a previous description of near-reef larval assemblages and a comparison of sampling methods (Brogan 1994). Here I report on the larval distributions of the common families. Three questions were addressed: (1) Which families utilize the nearreef habitat throughout development? (2) Is there evidence for larval retention among reef fishes? (3) Is larval retention restricted to families with non-pelagic eggs and large, well-developed hatchlings?

\section{METHODS}

Study sites and field methods. Plankton samples were collected in the Gulf of California (see Brogan 1994, Fig. 1) from June to August 1989 (125 samples, sites A to E) and July to August 1990 (40 samples, sites $A, C$, and E). Steep rocky shorelines continued below the surface as rocky reefs that extended $\sim 50 \mathrm{~m}$ offshore and reached depths of 15 to $30 \mathrm{~m}$. Sand bottoms extended beyond the reefs. A total of 1 to 4 transects, oriented perpendicular to shore, were established at each site. Three stations were sampied per transect. The first station was located along shallow reef substrate, a few to several meters from shore. Additional stations were located $\sim 20$ and $100 \mathrm{~m}$ seaward of the first. These stations will be referred to individually as 1,20 , and $100 \mathrm{~m}$ stations, and collectively as near-reef stations. Depths and bottom cover at these stations were 1 to $5 \mathrm{~m}$ over reef, 10 to $20 \mathrm{~m}$ over reef, and 20 to $30 \mathrm{~m}$ over sand, respectively. Stations on a transect were usually sampled in immediate succession, providing a 'complete' sample set. If sampling had to be terminated before all 3 stations were occupied the set was left 'incomplete.' A maximum of 1 set was collected with each gear type (see below) in a $24 \mathrm{~h}$ period.

A total of 00 plankton samples were collected with a light trap described by Brogan (1994). The light trap was suspended $1 \mathrm{~m}$ below the surface and it illuminated a volume $-5 \mathrm{~m}$ in radius. The reef surface was illuminated at $1 \mathrm{~m}$ stations. Sampling began $\sim 1 \mathrm{~h}$ after sunset and in most cases the light trap fished for $20 \mathrm{~min}$ per sample (see Brogan 1994 for details). The number of samples taken at 1,20 , and $100 \mathrm{~m}$ stations was 32 , 29 , and 27 , respectively. Two samples taken $-10 \mathrm{~m}$ from reefs were also included in some analyses. 
Most of the same transects were sampled during the day using a $0.5 \mathrm{~m}$ ring net $(0.5 \mathrm{~mm}$ mesh) fitted with a 3-point bridle and a flowmeter The net was towed parallel to shore at 1.0 to $1.5 \mathrm{~m} \mathrm{~s}^{-1}$ and the mean filtered volume was $108.4 \pm 41.7 \mathrm{~m}^{3}$ ( $\pm 1 \mathrm{SD}$ ). A.t $1 \mathrm{~m}$ stations a diver used a system of adjustable planes and weights to steer the net along reef surfaces at 1 to $5 \mathrm{~m}$ depth. Tows at 20 and $100 \mathrm{~m}$ stations were conducted as stepped oblique tows from $5.5 \mathrm{~m}$ depth to the surface (see Brogan 1994 for details). The number of tows taken at 1,20 , and $100 \mathrm{~m}$ stations was 26, 23, and 25 , respectively. One additional tow taken -50 to $100 \mathrm{~m}$ off a reef was also included in some analyses.

Other methods were used to make supplemental collections at the same sites. Demersal eggs were collected from known parents (24 species), reared in buckets until hatching, and the larvae were preserved in $5 \%$ formalin or $95 \%$ ethanol. Embryos of 4 livebearing species were dissected from preserved females. Nearly 100 species of pelagic juveniles and recently-settled reef fishes were collected with anesthetics, dip nets, a slurp gun, and a beach seine.

Laboratory methods and analyses. All fish larvae were removed from plankton samples with the aid of a stereomicroscope and identified to family or lower levels using literature sources (e.g. Leis \& Rennis 1983, Moser et al. 1984, Leis \& Trnski 1989) and my reference collection of newly-hatched larvae and recent recruits. Information on Gulf of California fish larvae is sparse, and identification below family is presently impossible for many specimens. Consequently, all analyses were done at the family level. For some families I have provided additional information at lower taxonomic levels in relevant parts of the results or discussion. Sixteen families of shorefishes (defined in Leis \& Trnski 1989), those contributing at least $0.25 \%$ of all larvae collected, were analyzed. These families will be referred to as the common families.

Larvae were measured as described by Brogan (1994) and lengths were plotted to assess size distributions at the near-reef stations. The size axes in these plots were chosen to reflect the size range from hatching (or birth) to settlement in benthic fishes, and hatching to juvenile transition in epipelagic fishes. Sizes at hatching, birth, settlement, and transition were estimated from my reference collection of newly hatched larvae, morphology of field-caught pelagic specimens, collections of recent recruits, and literature data. If information on Gulf species was not available, I substituted data on congeners or confamilials from other regions (see Brogan 1992).

Counts of larvae collected near reefs were pooled for each common family and compared to standard haul totals of the same families in an offshore Gulf of California survey (CalCOFI cruise 5706, Moser et al. 1973).
The offshore survey was conducted in June 1957, and it sampled 132 stations $\sim 5$ to $100 \mathrm{~km}$ off the coast. Oblique tows were taken with a $1 \mathrm{~m}$ ring net $0.5 \mathrm{~mm}$ mesh) through the upper $210 \mathrm{~m}$, depth permitting. Differences in collecting methods and time precluded a quantitative comparison of the near-reef and offshore surveys. The main purpose of the comparison was not to 'prove' cases of larval retention through offshore absences, but to try and refute retention by demonstrating that larvae common near reefs also occurred in significant numbers beyond $5 \mathrm{~km}$ from shore. In addition, the ratio of the 2 counts (offshore: near-reef) was used as a crude indicator of how strongly a family tended to be distributed offshore or near reefs relative to other families.

Larval concentrations (larvae per $100 \mathrm{~m}^{3}$ for the plankton net, larvae per 20 min for the light trap) were compared between the 1,20 , and $100 \mathrm{~m}$ stations using the non-parametric Friedman test for matched sets (Conover 1980). Light-trap and plankton-net samples were analyzed separately since gear biases and/or diel migrations frequently led to characteristic differences in size structure of catches between gears. Replication was achieved by collecting multiple sets of samples across days and transects. Sites and transect locations were selected for similarity in habitat and topography. Pooling of transects obscures any potential differences in larval distributions between sites and times, but any patterns that emerge should be robust. The analysis for each family-gear combination was based on a minimum of 5 sample sets, each with at least 5 larvae of that family. Only complete sample sets were included. A total of 8 families were tested for both gears, and 6 families were tested for the plankton net only. I used the very conservative Dunn-Šidák method (Sokal \& Rohlf 1981) to adjust $\alpha$ levels and ensure that the probability of a Type 1 error anywhere among the 22 Friedman tests was $<0.1$ (i.e. $\alpha^{\prime}$ for individual Friedman tests was 0.0048 ). All significant tests were followed by a nonparametric multiple comparison (Conover 1980), also using $\alpha^{\prime}=0.0048$, to determine which distances from reefs had significantly different larval concentrations.

Data on development of larvae at hatching were taken from a variety of sources. I considered 4 morphological indicators: body size; amount of yolk remaining; darkness of eye pigment; and formation of the mouth. Large body size, little yolk remaining, dark eye pigment, and a fully-formed mouth were equated with a well-developed larva. Most data on reef species were taken from my reference collection of newly hatched larvae. Data on other benthic species and epipelagic species were taken from the literature. In some cases, information on congeners or confamilials from other regions was substituted (e.g. Leis \& Rennis 1983, Moser et al. 1984, Thresher 1984, Leis \& Trnski 1989). 
Table 1 Common families in near-reef larval collections. Estimated number of species, dominant taxa (if clear dominants were present), and adult habitat are given

\begin{tabular}{|llll|}
\hline Family & Species & Dominant taxa & Adult habitat \\
\hline Balistidae & 1 & Balistes polylepis & Reef \\
Blenniidae & 4 & Ophioblennius steindachneri & Reef \\
Bythitidae & $3-4$ & Ogilbia spp. & Reef \\
Carangidae & 8 & Oligoplites spp. & Epipelagic \\
Chaenopsidae & $9-11$ & Acanthemblemaria spp., & Reef \\
& & Stathmonotus sinuscalifornici & \\
Clupeidae & $2+$ & Opisthonema spp. & Epipelagic \\
Dactyloscopidae & $5-6$ & & Sand \\
Engraulididae & $?$ & & Epipelagic \\
Gerreidae & $4-6$ & Eucinostomus spp. & Sand \\
Gobiesocidae & $4-5$ & & Reef \\
Gobiidae & $4+$ & & Sand/reef \\
Haemulidae & $5+$ & Pomadasys spp.? & Sand/reef \\
Labrisomidae & 6 & Paraclinus sini & Reef \\
Pomacentridae & 4 & & Reef \\
Scombridae & $3-4$ & Auxis spp. & Epipelagic \\
Tripterygiidae & 4 & Axoclinus carminalis, & Reef \\
& & A.nigricaudus & \\
\hline
\end{tabular}

catch, $98.7 \%$ of the light-trap catch, and $\sim 75$ species. Catch statistics for these families are listed in Table 2.

\section{Larval size distributions}

Two size distribution patterns were observed among the epipelagic families. Clupeid and engraulidid larvae ranged from recently hatched specimens ( $2 \mathrm{~mm}$ ) with unpigmented eyes and substantial yolk remaining, to large specimens ( $-30 \mathrm{~mm})$ completing transformation, including all intermediate size classes (Fig. 1A, B). In contrast, a large portion of carangid and scombrid larval development was represented by only a few specimens. Most larvae were $<5 \mathrm{~mm}$ (Fig. 1C, D).

The 2 families of sandy-bottom fishes were represented by larvae of several species each. Among dactyloscopids, the full pelagic size range of Dactyloscopus spp. was collected (settlement occurs at 9 to $10 \mathrm{~mm}$ ), but only 5 Dactylagnus mundus and Myxodagnus opercularis larvae between $9 \mathrm{~mm}$ and settlement (13 to $15 \mathrm{~mm}$ ) were collected, even though smaller larvae were common (Fig. 1E). Gerreid larvae ranged from 1.5 to $19 \mathrm{~mm}$ (Fig. 1F). This encompasses the entire pelagic period of the dominant taxon, Eucinostomus spp., which settles

Table 2. Catch statıstics for the common families. Number of larvae collected, average larval concentration ( \pm 1 SD), and maximum larval concentration are given. Concentrations were standardized as larvae per $100 \mathrm{~m}^{3}$ (plankton net) or larvae per 20 min (light trap)

\begin{tabular}{|c|c|c|c|c|c|c|}
\hline \multirow[t]{2}{*}{ Family } & \multicolumn{3}{|c|}{ _ Plankton net } & \multicolumn{3}{|c|}{ - Light trap } \\
\hline & No. & Average conc. & Max. conc. & No. & Average conc. & Max. conc. \\
\hline Clupeidae & 3875 & $47.7 \pm 114.9$ & 827.0 & 4631 & $50.90 \pm 321.65$ & 3037.0 \\
\hline Tripterygiidae & 3122 & $38.4 \pm 60.4$ & 269.9 & 1267 & $13.83 \pm 33.75$ & 192.0 \\
\hline Gobijdae & 2001 & $24.6 \pm 67.8$ & 432.0 & 546 & $5.95 \pm 22.47$ & 148.0 \\
\hline Chaenopsidae & 1826 & $22.5 \pm 53.2$ & 328.6 & 690 & $7.58 \pm 18.04$ & 76.0 \\
\hline Labrisomidae & 992 & $12.2 \pm 28.9$ & 182.0 & 1050 & $11.48 \pm 30.55$ & 149.0 \\
\hline Haemulidae & 744 & $9.2 \pm 21.0$ & 93.9 & 52 & $0.58 \pm 3.17$ & 29.0 \\
\hline Pomacentridae & 743 & $9.1 \pm 20.3$ & 118.0 & 253 & $2.74 \pm 9.49$ & 53.0 \\
\hline Carangidae & 658 & $8.1 \pm 15.5$ & 73.0 & 6 & $0.07 \pm 0.24$ & 1.0 \\
\hline Dactyloscopidae & 471 & $5.8 \pm 19.5$ & 152.0 & 7 & $0.08 \pm 0.34$ & 2.0 \\
\hline Balistidae & 467 & $5.7 \pm 20.0$ & 124.0 & 0 & 0 & 0 \\
\hline Gerreidae & 452 & $5.6 \pm 11.3$ & 48.0 & 582 & $6.42 \pm 14.49$ & 85.0 \\
\hline Scombridae & 278 & $3.4 \pm 9.8$ & 66.0 & 3 & $0.03 \pm 0.18$ & 1.0 \\
\hline Gobiesocidae & 274 & $3.4 \pm 10.3$ & 73.8 & 39 & $0.42 \pm 1.12$ & 7.6 \\
\hline Engraulididae & 156 & $1.9 \pm 5.5$ & 32.0 & 130 & $1.44 \pm 5.01$ & 35.0 \\
\hline Blenniidae & 81 & $1.0 \pm 4.9$ & 35.9 & 10 & $0.11 \pm 0.37$ & 2.0 \\
\hline Bythitidae & 62 & $0.8 \pm 3.3$ & 27.6 & 16 & $0.18 \pm 0.94$ & 7.0 \\
\hline
\end{tabular}


anywhere between 9 and $19 \mathrm{~mm}$. A group of gerreid larvae with a mode at $14 \mathrm{~mm}$ was present at 20 and $100 \mathrm{~m}$ stations (collected on 15 dates), but was essentially absent from $1 \mathrm{~m}$ stations.

All pelagic size classes of the 2 families with both sandy-bottom and reef species were present near reefs. Gobiids ranged from 2 to $12.5 \mathrm{~mm}$, but only $6.7 \%$ of the larvae were $>5 \mathrm{~mm}$ (Fig. 1G). Although they were poorly collected by the plankton gear, direct observations indicated that gobiids between 5.3 and $12.5 \mathrm{~mm}$ formed large aggregations adjacent to reefs. Nearly $93 \%$ of the gobiids $>5 \mathrm{~mm}$ were taken at $1 \mathrm{~m}$ stations (collected on 13 dates) and this may reflect the location of larval aggregations. Haemulid larvae in plankton collections ranged from 2 to $11.5 \mathrm{~mm}$ (Fig. 1H), and larvae between 6 and $12 \mathrm{~mm}$ formed aggregations near reefs. Plankton tows at $1 \mathrm{~m}$ stations had a proportionally greater representation of larvae $>5 \mathrm{~mm}$ than 20 or $100 \mathrm{~m}$ stations, but the total number taken at $1 \mathrm{~m}$ stations was small and the large larvae were taken on just 3 dates.

For 3 of the reef fish families, only a small portion of the pelagic size range was collected. Balistes polylepis larvae (the only balistid I collected) ranged from 1.5 to $3 \mathrm{~mm}$ (Fig. 1I), but settlement does not occur until at least $27 \mathrm{~mm}$. All blenniid larvae were between 2 and $2.5 \mathrm{~mm}$ (Fig. 1J). The dominant species, Ophioblennius steindachneri (95\% of blenniid larvae), settles between 37 and $66 \mathrm{~mm}$, while the other taxa I collected (Hypsoblennius spp. and Entomacrodus chiostictus) settle between 12 and $20 \mathrm{~mm}$. Pomacentrid larvae ranged from 2 to $19 \mathrm{~mm}$, but $99 \%$ of the specimens were $<3.5 \mathrm{~mm}$ (Fig. 1K). Abudefduf troschelii, Chromis limbaughi, and Stegastes spp. settle as small as 8 to $9 \mathrm{~mm}$, but Microspathodon dorsalis does not settle until 14 to $15 \mathrm{~mm}$, and Chromis atrilobata typically settles at 18 to $20 \mathrm{~mm}$. Of the 7 larvae $>3.5 \mathrm{~mm}, 5$ were settlement stage Stegastes spp. (10 to $12 \mathrm{~mm})$, and 1 was a settlement stage $C$. atrilobata (19 mm).

All pelagic size classes of the other 5 families of reef fishes were taken in collections near reefs. Bythitid larvae (all Ogilbia spp.) ranged from 5 to $9 \mathrm{~mm}$ (Fig. 1L). This encompasses the brief pelagic period of these live-bearing fishes. Chaenopsid larvae ranged from 2.5 to $17.5 \mathrm{~mm}$, but few larvae $>12 \mathrm{~mm}$ were collected (Fig. 1M). Species of Stathmonotus, Coralliozetus, and Emblemaria may settle as small as 9 to $10 \mathrm{~mm}$, Acanthemblemaria, Ekemblemaria, and Protemblemaria spp. typically settle at 12 to $14 \mathrm{~mm}$, and Chaenopsis spp. do not settle until $\sim 18 \mathrm{~mm}$. Five of the genera were represented by $>50$ larvae (Ekemblemaria and Protemblemaria were rare), and of these only Chaenopsis had a large gap in its size distribution. Chaenopsis larvae from 9 to $18 \mathrm{~mm}$ were not taken, but smaller larvae were common. Gobiesocids ranged in size from 2 to $8 \mathrm{~mm}$ (Fig. 1N). Gulf species settle between 7.1 and $9.5 \mathrm{~mm}$. Labrisomids ranged from 2 to $20.5 \mathrm{~mm}$, but only a few larvae were $>10 \mathrm{~mm}$ (Fig. 10). Paraclinus sini (the dominant species) and Exerpes asper typically settle at 8 to $10 \mathrm{~mm}$, while Malacoctenus spp. settle at 12 to $15 \mathrm{~mm}$. Malacoctenus larvae were common up to $10 \mathrm{~mm}$, and specimens between 10 and $15 \mathrm{~mm}$ were occasionally collected. Labrisomus spp. settle at 15 to $24 \mathrm{~mm}$, but of the 12 larvae I collected, 11 were $<5 \mathrm{~mm}$. The single larger specimen measured $20.5 \mathrm{~mm}$. Tripterygiid larvae ranged from 2 to $13 \mathrm{~mm}$, and the proportion of small larvae in light-trap samples decreased with distance from reefs (Fig. 1P). Gulf tripterygiids settle at 9 to $13 \mathrm{~mm}$.

\section{Counts of larvae near reefs versus offshore}

Nine of the 16 common families were collected in the offshore survey (Table 3). Seven were common offshore, pomacentrids were caught in moderate numbers, and balistids were rarely collected. Seven other families - 6 families of reef fishes and dactyloscopids - were apparently absent from offshore collections. The ratio of counts (offshore:near-reef) varied from 10.11 to 0 . Among the 9 families collected in both surveys, scombrid and engraulidid larvae had the highest relative counts offshore, and balistid larvae had the highest relative count near reefs (Table 3 ).

Table 3. Comparison of larval counts from near reefs (this study) and offshore (from Moser et al. 1973), and the ratio of the 2 counts (offshore: near-reef)

\begin{tabular}{|lrcc|}
\hline Family & Near-reef & Offshore & Ratio \\
\hline Scombridae & 281 & 2842 & 10.11 \\
Engraulididae & 286 & 2880 & 10.07 \\
Clupeidae & 8506 & 23495 & 2.76 \\
Gerreidae & 1034 & 2064 & 2.00 \\
Carangidae & 664 & 1317 & 1.98 \\
Haemulidae & 796 & 1373 & 1.72 \\
Gobiidae & 2547 & 1301 & 0.51 \\
Pomacentridae & 996 & 218 & 0.22 \\
Balistidae & 467 & 6 & 0.01 \\
Bythitidae & 78 & $?{ }^{\circ}$ & 0 \\
Blenniidae & 91 & 0 & 0 \\
Gobiesocidae & 313 & 0 & 0 \\
Dactyloscopidae & 478 & 0 & 0 \\
Labrisomidae & 2042 & 0 & 0 \\
Chaenopsidae & 2516 & 0 & 0 \\
Tripterygiidae & 4389 & 0 & 0 \\
& \multicolumn{4}{c}{0} \\
'Bythitids might have been included among 'Ophidiidae- \\
Brotulidae' larvae collected offshore, but it is unlikely \\
that Ogilbia spp. were among them (see 'Discussion') \\
\hline
\end{tabular}



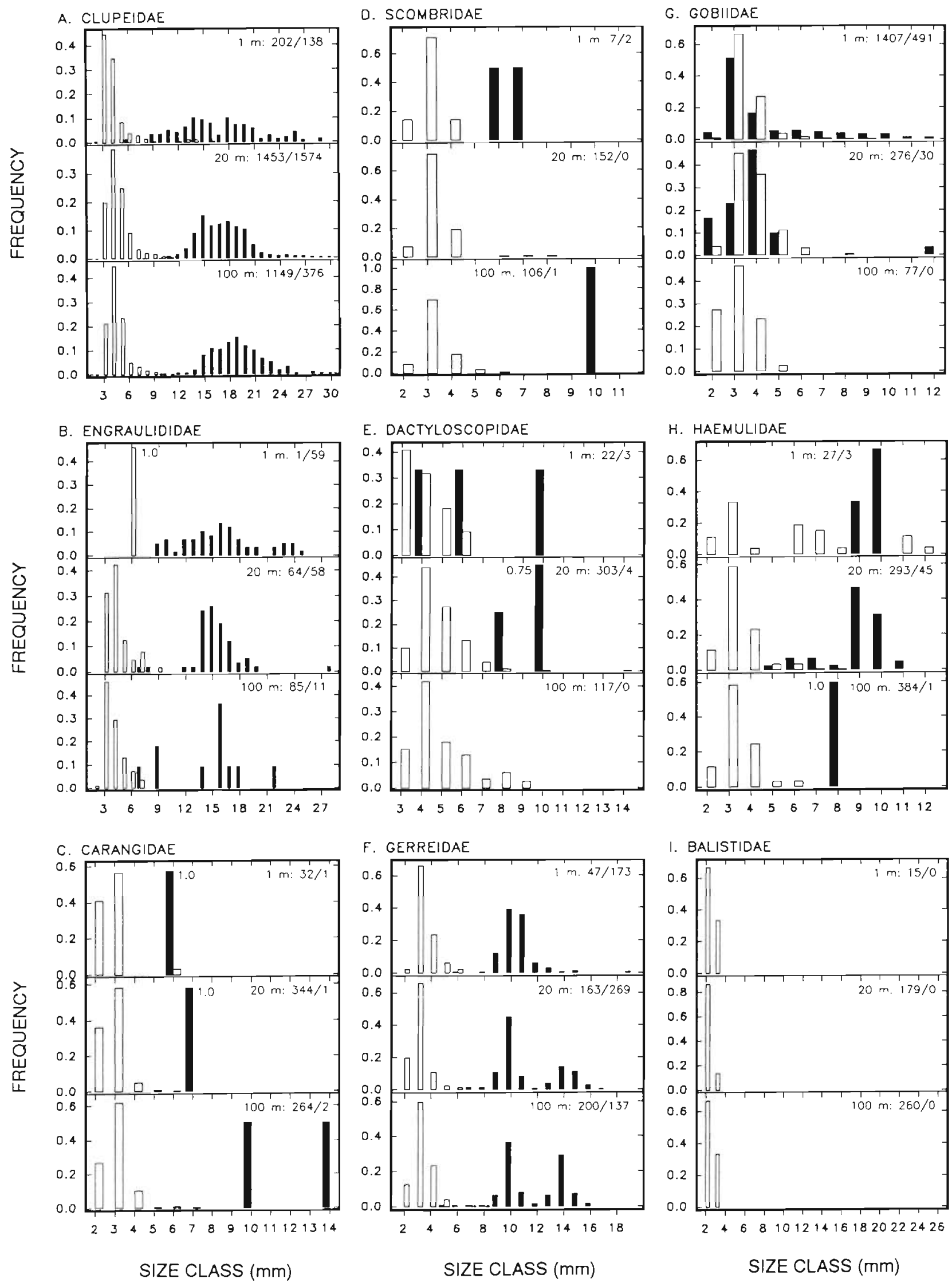

F. GERREIOAE
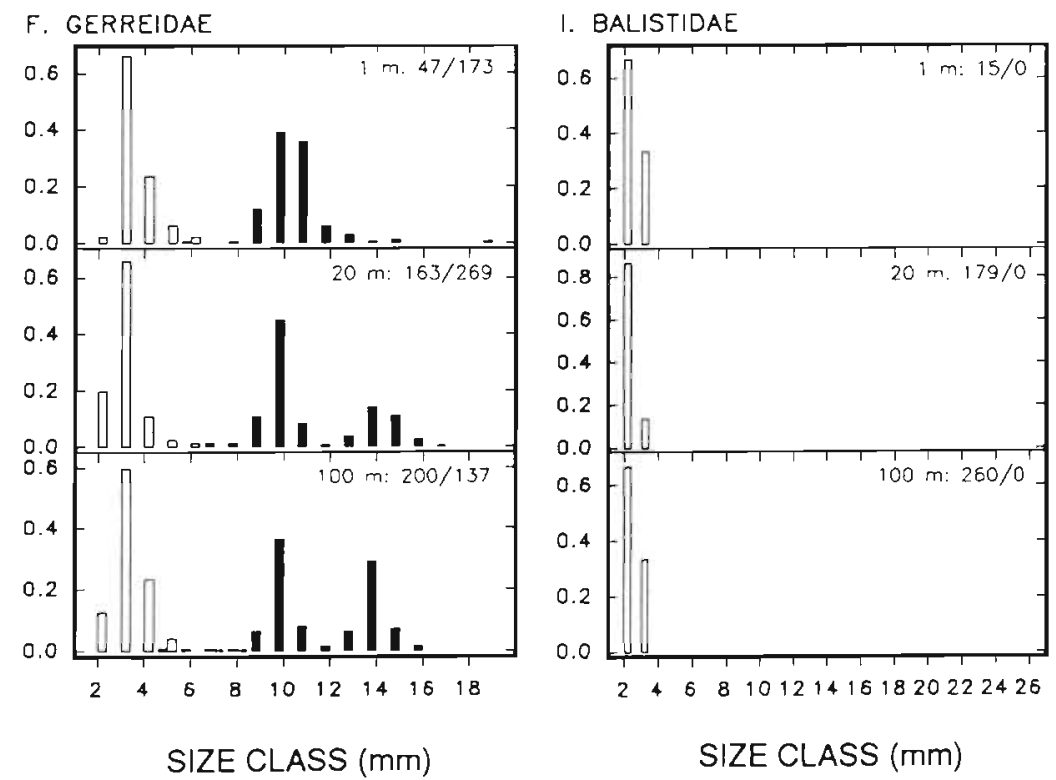

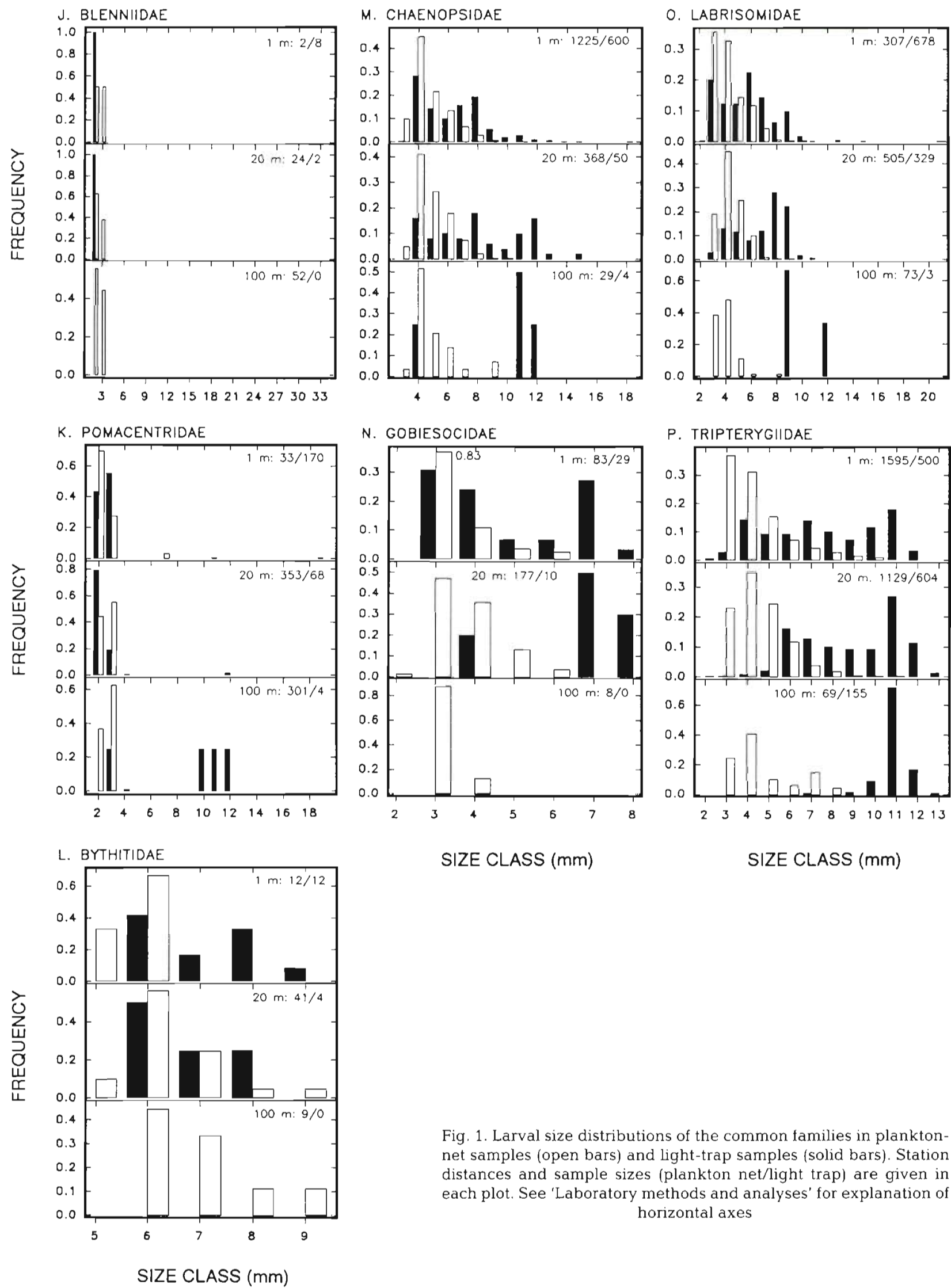

SIZE CLASS (mm)

SIZE CLASS (mm)

Fig. 1. Larval size distributions of the common families in planktonnet samples (open bars) and light-trap samples (solid bars). Station distances and sample sizes (plankton net/light trap) are given in each plot. See 'Laboratory methods and analyses' for explanation of horizontal axes 


\section{Larval concentration gradients}

The null hypothesis of equal larval concentrations at 1,20 , and $100 \mathrm{~m}$ stations was rejected by the Friedman test in 20 of 22 cases. Subsequent multiple comparisons indicated that the significant concentration gradients fell into 6 basic patterns, designated $A$ through F. These patterns, and the taxa within each, were ordered according to increasing larval concentration at the $1 \mathrm{~m}$ stations (Table 4). Pattern A is characterized by low concentration at $1 \mathrm{~m}$ and similarly high concentrations at 20 and $100 \mathrm{~m}$. Patterns $B$ and $C$ are characterized by highest concentrations at $20 \mathrm{~m}$, and significantly lower concentrations at $1 \mathrm{~m}$ or 1 and $100 \mathrm{~m}$. Patterns D, E, and F are characterized by highest concentrations at $1 \mathrm{~m}$, or 1 and $20 \mathrm{~m}$, and a significant decrease in larval concentration seaward.

Families collected in the offshore survey had concentration pattern $A$ in plankton tow sets, with the exception of gobiids (Table 4). Larval concentrations at $1 \mathrm{~m}$ stations were 90 to $100 \%$ lower than at the station distance with the highest concentration (20 or $100 \mathrm{~m}$ ). Mean concentrations of gobiid larvae were highest at
$1 \mathrm{~m}$ stations and lowest at $100 \mathrm{~m}$ stations, but the differences were not statistically significant. However, failure to reject the null hypothesis for Gobiidae (PN) may constitute a Type II error since the $\alpha^{\prime}$ derived by the Dunn-Sidák method is so conservative (0.0048). Fewer tests were possible with light-trap data. Clupeids and gerreids were most concentrated at $20 \mathrm{~m}$ stations (pattern B or C), and pomacentrids and gobiids were highly concentrated at $1 \mathrm{~m}$ stations, where 88 to $91 \%$ of the larvae were taken (pattern F). The variation in engraulidid mean concentrations across station distances resembled pattern $D$, but the differences were not significant ( $p=0.039)$.

In contrast, none of the families absent from the offshore survey had concentration pattern A (Table 4). In plankton tow sets, dactyloscopids and labrisomids were most concentrated at $20 \mathrm{~m}$ stations, where 70 to $78 \%$ of the specimens were collected (patterns B and C). Tripterygiids, gobiesocids, and chaenopsids were most concentrated at 1 and $20 \mathrm{~m}$ stations, and mean concentrations at $100 \mathrm{~m}$ dropped 90 to $97 \%$ from the maximum (pattern D). In light-trap samples, tripterygiids had pattern D, and labrisomids and chaenopsids

Table 4. Comparison of larval concentrations at 1,20, and $100 \mathrm{~m}$ stations. Codes after families indicate gear type (PN: plankton net; LT: light trap). Sets: number of replicates for each test. Under- and overlining denotes concentrations that did not differ significantly in a multiple comparison $\left(\alpha^{\prime}=0.0048\right)$. Relative concentrations are given for ease of comparisons, but statistics were based on ranks of actual concentrations. Families were grouped according to their concentration gradient pattern (A through $F$ ). ns: not significant

\begin{tabular}{|c|c|c|c|c|c|c|c|}
\hline \multirow[t]{2}{*}{ Family } & \multicolumn{3}{|c|}{ Friedman tests } & \multicolumn{4}{|c|}{ - Mean relative concentrations } \\
\hline & Sets & $\mathrm{T}_{2}$ & $\mathrm{p}>F$ & $1 \mathrm{~m}$ & $20 \mathrm{~m}$ & $100 \mathrm{~m}$ & Pattern \\
\hline Engraulididae (PN) & 6 & 18.793 & 0.000410 & 0 & 0.473 & $\underline{0.527}$ & A \\
\hline Gerreidae (PN) & 9 & 17.714 & 0.000088 & 0.006 & $\underline{0.474}$ & $\underline{0.520}$ & A \\
\hline Scombridae (PN) & 10 & 11.289 & 0.000665 & 0.037 & $\underline{0.473}$ & $\underline{0.490}$ & A \\
\hline Pomacentridae $(\mathrm{PN})$ & 17 & 32.468 & $<0.000001$ & 0.041 & $\underline{0.385}$ & $\underline{0.574}$ & A \\
\hline Haemulidae (PN) & 13 & 20.341 & $<0.000007$ & 0.048 & 0.358 & $\underline{0.594}$ & A \\
\hline Carangidae (PN) & 14 & 39.000 & $<0.000001$ & 0.048 & 0.487 & 0.465 & A \\
\hline Clupeidae (PN) & 14 & 40.083 & $<0.000001$ & 0.048 & $\underline{0.553}$ & 0.398 & A \\
\hline Balistidae $(P N)$ & 11 & 30.333 & 0.000001 & 0.052 & 0.386 & $\underline{0.563}$ & $A$ \\
\hline Dactyloscopidae (PN) & 5 & 13.273 & 0.002876 & $\underline{0.008}$ & $\overline{0.776}$ & $\overline{0.217}$ & B \\
\hline Clupeidae (LT) & 14 & 8.267 & 0.001857 & 0.146 & $\overline{0.662}$ & $\overline{0 . \overline{192}}$ & B \\
\hline Labrisomidae (PN) & 13 & 14.878 & 0.000763 & $\underline{0.143}$ & 0.699 & 0.158 & $\mathrm{C}$ \\
\hline Gerreidae (LT) & 10 & 14.878 & 0.000154 & $\underline{0.186}$ & 0.566 & 0.248 & C \\
\hline Tripterygiidae (PN) & 17 & 20.303 & 0.000002 & $0.3 \underline{64}$ & $\underline{0.577}$ & 0.059 & $\mathrm{D}$ \\
\hline Gobiesocidae (PN) & 5 & 12.667 & 0.003317 & 0.391 & $0.57 \underline{2}$ & 0.037 & $\mathrm{D}$ \\
\hline Tripterygiidae (LT) & 15 & 7.368 & 0.002686 & $\underline{0.515}$ & 0.366 & 0.119 & $\mathrm{D}$ \\
\hline Chaenopsidae (PN) & 14 & 16.949 & 0.000019 & 0.662 & 0.321 & 0.017 & $\mathrm{D}$ \\
\hline Engraulididae (LT) & 7 & 4.302 & 0.039028 & 0.542 & 0.413 & 0.044 & ns \\
\hline Gobiidae (PN) & 14 & 5.780 & 0.008380 & 0.689 & $\underline{0.236}$ & 0.075 & ns \\
\hline Labrisomidae (LT) & 13 & 37.541 & $<0.000001$ & 0.795 & 0.204 & 0.001 & $E$ \\
\hline Chaenopsidae (LT) & 13 & 55.500 & $<0.000001$ & 0.910 & 0.087 & 0.003 & $E$ \\
\hline Pomacentridae (LT) & 7 & 12.000 & 0.001372 & 0.880 & $\underline{0.104}$ & $\underline{0.016}$ & F \\
\hline Gobildae (LT) & 10 & 32.831 & 0.000001 & 0.907 & $\underline{0.093}$ & $\underline{0}$ & $\mathrm{~F}$ \\
\hline
\end{tabular}


had pattern E. Mean concentrations of these 3 families at $100 \mathrm{~m}$ stations were $77 \%$ to over $99 \%$ lower than at $1 \mathrm{~m}$ stations. Dactyloscopids and gobiesocids in lighttrap samples and bythitids in both gears appeared to be most concentrated at $1 \mathrm{~m}$ or 1 and $20 \mathrm{~m}$ stations and to have greatly reduced concentrations at $100 \mathrm{~m}$ stations, but small sample sizes precluded statistical analyses (number of larvae collected at each station given in Fig. 1E, L, N).

It is worth noting that 7 of the 8 families analyzed for both gears (Engraulididae, Gerreidae, Pomacentridae, Clupeidae, Labrisomidae, Chaenopsidae, and Gobiidae) had concentration gradient patterns that differed between gears. In every case, sets taken at night with the light trap had a greater proportion of the larvae captured nearer reefs than in daytime plankton-tow sets. Tripterygiids showed a similar shift in distribution of relative concentrations, but not of sufficient magnitude to change pattern (Table 4).

\section{Egg type and larval morphology at hatching}

There was substantial variation in the development of larvae at hatching (Table 5) The minimum size at hatching ranged from 1.0 to $2.5 \mathrm{~mm}$ among pelagicspawning families, and from 1.4 to $6.3 \mathrm{~mm}$ in nonpelagic spawners. The largest larvae were produced by Ogilbia spp. (Bythitidae), a live-bearing taxon. Larvae of pelagic spawners had substantial yolk remaining, no eye pigment, and incompletely-formed mouths. In contrast, the larvae of most non-pelagic spawners had little or no yolk remaining, dark eye pigment, and fully formed mouths. Larvae of Balistes polylepis (Balistidae) were a notable exception. They were small and poorly developed, resembling larvae of pelagic spawners more than larvae of the other demersal spawners (Table 5).

\section{DISCUSSION}

Data from this study and others suggest that the common families can be placed in 3 larval distribution categories. The first group includes balistids, blenniids, carangids, pomacentrids, and scombrids. Larvae of these families were common near Gulf reefs, but they were also common in the offshore survey (Carangidae, Pomacentridae, Scombridae), or at least there is reason to believe they may occur offshore with some regularity despite being rare or absent on CalCOFI 5706 (Balistidae, Blenniidae; see Springer 1962, Stevens \& Moser 1982, Richards 1984, Young et al. 1986, Leis \& Goldman 1987, Clarke 1991). Mean larval concentrations of these families were lowest at $1 \mathrm{~m}$ stations, except for pomacentrids in light-trap samples (Table 4). Most Pomacentridae (LT) were hatchlings, and they were probably most concentrated at $1 \mathrm{~m}$ stations because nests were most abundant there and hatching occurred just after dark when the light-trap was fishing. During daytime plankton tows, small pomacentrids were most concentrated at $100 \mathrm{~m}$ stations. Catches of the other families were also dominated by small and recently hatched larvae: size distributions provided no evidence that development was completed in the immediate vicinity of reefs (Fig. 1). Whether the absence of intermediate-sized and/or large larvae was due to offshore dispersal, ontogenetic changes in vertical distribution, or gear avoidance is unknown. In any case, larval retention in the immedi-

Table 5. Egg type and larval morphology at hatching for the common families

\begin{tabular}{|c|c|c|c|c|c|}
\hline \multirow[t]{2}{*}{ Family } & \multirow[t]{2}{*}{ Egg type } & \multicolumn{4}{|c|}{ - Larval morphology at hatching } \\
\hline & & Size $(\mathrm{mm})$ & Yolk size & Eye pigment & Mouth formed? \\
\hline Carangidae & Pelagic & $1.0-2.0$ & Large & None & No \\
\hline Gerreidae & Pelagic & 1.4 & Large & None & No \\
\hline Engraulididae & Pelagic & $1.5-2.5$ & Large & None & No \\
\hline Haemulidae & Pelagic & $1.7-2.8$ & Large & None & No \\
\hline Clupeidae & Pelagic & $2.3-3.0$ & Large & None & No \\
\hline Scombridae & Pelagic & $2.5-3.0$ & Large & None & No \\
\hline Balistidae & Demersal & $1.4-1.5$ & Large & None & No \\
\hline Pomacentridae & Demersal & $1.9-2.3$ & Small & Pale-dark & Yes \\
\hline Blenniidae & Demersal & $2.1-2.5$ & None-small & Dark & Yes \\
\hline Gobiidae & Demersal & $2.1-3.4$ & None-small & Dark & Yes \\
\hline Gobiesocidae & Demersal & 2.4 & Small & Dark & Yes \\
\hline Labrisomidae & Demersal & $2.7-4.1$ & None-small & Dark & Yes \\
\hline Tripterygiidae & Demersal & 2.9 & None-small & Dark & Yes \\
\hline Chaenopsidae & Demersal & $3.5-4.8$ & None-small & Dark & Yes \\
\hline Dactyloscopidae & Brooded & 4.1 & None-small & Dark & Yes \\
\hline Bythitidae & Live-bearer & $6.3-7.3$ & None-small & Dark & Yes \\
\hline
\end{tabular}


ate vicinity of reefs appears to be unlikely for this group of families.

The second group of families (Clupeidae, Engraulididae, Gerreidae, Haemulidae, Gobiidae) also had broad larval distributions including near-reef and offshore areas, but unlike the first group, larvae of all sizes were collected near reefs (Fig. 1). Mean larval concentrations in plankton tow sets were generally high at 20 and $100 \mathrm{~m}$ stations and low at $1 \mathrm{~m}$ stations, but there was a suggestion that highest concentrations were located closer to the reef in light-trap sets (Table 4). Apparent shifts in distributions could have been due to diel and/or ontogenetic effects since both time of day and the size of larvae differed between plankton-tow and light-trap samples (see Brogan 1994). Available data do not support a general pattern of larval retention in these families, but the possibility that some component species have such a distribution can not be excluded either (see next paragraph).

Concentration patterns of gobiids differed from other members of the second group. These patterns, along with direct observations of larval aggregations, suggest that gobiid larvae were concentrated along shallow reefs during day and night. This is intriguing because gobiids were also abundant offshore (Table 3 ). A testable hypothesis is that some reef-dwelling gobiids are retained on reefs throughout development, while other species from a variety of habitats are dispersed offshore. Rearing trials indicated that gobiid larvae from aggregations were reef species (Aruma histrio, Barbulifer pantherinus, and Gobiosoma sp.), and a brief examination of several offshore collections suggested little or no overlap between the kinds of larvae in the 2 habitats. However, larval taxonomic studies and species-level distribution analyses are needed to verify that some gobiids are retained over reefs throughout development.

Larval retention near Gulf reefs is most likely among the third group of families (Bythitidae, Chaenopsidae, Dactyloscopidae, Gobiesocidae, Labrisomidae, Tripterygiidae). Larvae of these families were absent from offshore collections, all pelagic size classes were collected over reefs, and, where data were available, larval concentrations dropped sharply from maxima at 1 and/or $20 \mathrm{~m}$ stations to low values at $100 \mathrm{~m}$ stations (average decreases of 72.0 to $99.9 \%$, Table 4 ). In the section below I explore alternative interpretations of these observations

The absence of larvae from offshore collections on CalCOFI cruise 5706 could have resulted from the absence or rarity of larvae offshore (retention supported), or larvae may have been collected but left unidentified, misidentified, or masked by taxonomic changes. For example, larval chaenopsids, dactyloscopids, and labrisomids were essentially unknown at the time.
However, Moser et al. (1973) recognized larvae of these taxa as blennioids and included them under Clinidae (see next paragraph). Bythitid larvae might have been included with the 'Ophidiidae-Brotulidae' reported from offshore (see Cohen \& Nielsen 1978 for taxonomic changes), but given their short pelagic duration (inferred from birth sizes of 6.3 to $7.3 \mathrm{~mm}$ and settlement sizes of 9.5 to $10.5 \mathrm{~mm}_{\mathrm{i}}$ Brogan 1992), it is unlikely that Ogilbia spp. were collected offshore.

Even if larvae were absent offshore during cruise 5706 (June 1957), they could be present at other times, for example later in the summer spawning season. Offshore Gulf waters were also sampled in August 1957 (CalCOFI cruise 5708), but the material has not been fully worked up (H. G. Moser pers. comm.). I examined collections from 15 stations on cruise 5708,10 of them among the closest to rocky shores ( 5 to $10 \mathrm{~km})$. Bythitids, chaenopsids, dactyloscopids, gobiesocids, labrisomids, and tripterygiids were not present. These families were not reported on 5 winter and spring cruises either (Moser et al. 1973), but 2 of the occurrences of 'Clinidae' reported on cruise 5704 were based on labrisomids, dactyloscopids, and possibly chaenopsids. Both occurrences were from the northern Gulf, where the great tidal range (to $10 \mathrm{~m}$. Maluf 1983) and gently sloping bottom result in vigorous flushing and frequent exposure of nearshore habitats, including the predominantly intertidal reefs (Thomson et al. 1987). This suggests that under some circumstances larvae from the third group of families may be subject to offshore transport, but the available evidence indicates that such events are infrequent and involve relatively few individuals.

The concentration gradients available for this group of families were consistent with larval retention, but other distribution patterns could produce similar gradients. For example, larvae could have been transported away from reefs in the longshore direction to sandy shores where I did not sample. Such a nearshore distribution, rather than retention near reefs, is most likely for dactyloscopid larvae since aduits are found along sandy shores as well as in sandy patches of reefs. It is also possible that the concentration gradients reflected variation in influence of the epibenthos since plankton tows at $1 \mathrm{~m}$ stations were restricted to within $2 \mathrm{~m}$ of the bottom, while tows at 20 and $100 \mathrm{~m}$ stations came no closer to this layer than -3 and $13 \mathrm{~m}$, respectively. Parallel variation in influence of the epibenthos probably affected light-trap samples. Thus, epibenthic larvae could have appeared most concentrated at $1 \mathrm{~m}$ stations even if similar larval concentrations extended along the bottom to the seaward margin of reefs (retention supported) or appreciably beyond (retention rejected). Whether any Gulf reef fishes have larvae that are primarily epibenthic is unknown. Epibenthic fish larvae 
are known from a variety of habitats in other regions (e.g. Powles 1977, Barnett et al. 1984, Marliave 1986, Leis 1986b, Steffe 1990), but the off-reef epibenthos has been poorly studied. It did not appear to be an important habitat for larvae of reef fishes near Lizard Island, Great Barrier Reef (Leis et al. 1989).

Progress in larval taxonomy and more sophisticated sampling programs are needed to further address the issue of larval retention near Gulf reefs. However, this study has shown that there is pronounced spatial structure in larval fish distributions on a tens of meters scale near reefs, and that the distributions vary in characteristic ways among families. The larvae of at least 11 families, including epipelagic, sandy-bottom, and reef fishes, appeared to utilize the near-reef habitat throughout development. Although available evidence was inconsistent with retention for several of these families, it was consistent with retention for at least 5 others (Bythitidae, Chaenopsidae, Gobiesocidae, Labrisomidae, Tripterygiidae, and perhaps some Gobiidae). Larval retention is likely for at least some of the $30+$ species I collected from these families.

It is noteworthy that the taxa with distributions most suggestive of larval retention all have non-pelagic eggs and well-developed hatchlings (Table 5). Larvae of pelagic-spawning reef fish families were rare in my collections $13.35 \%$ of shorefish larvae versus $12.02 \%$ offshore), and neither they nor a demersal spawner with small, poorly developed larvae (Balistes polylepis) appeared to remain near reefs. Thus, retention is not randomly distributed among families, nor is it merely due to conservation of passive larvae (e.g. Black et al. 1991. Black 1993). More likely, larval retention is dependent on advanced sensory and motor skills that are developed only in the larger larvae produced by some non-pelagic spawners. It is interesting that blenniid and pomacentrid larvae did not appear to remain near reefs, even though their egg and larval traits were similar to taxa that did (Table 5). This suggests that non-pelagic eggs and well-developed hatchlings provide an opportunity for retention, but that other taxon-specific factors will ultimately determine whether such a distribution is realized.

I am aware of only 2 other studies that examined larval distributions on a fine scale within $100 \mathrm{~m}$ of reefs. Marliave (1986) found that larvae of 4 demersalspawning families (Cottidae, Gobiesocidae, Pholididae, Stichaeidae) were concentrated within a few meters of rocky reefs in British Columbia, Canada, and rare or absent by $500 \mathrm{~m}$ offshore. Larvae of all size classes were present, and some taxa formed schools that selected areas of reduced flow (Marliave 1986, pers. comm.). In contrast, Kobayashi (1989) found no evidence for retention of fish larvae over coral reefs in Kaneohe Bay, Hawaii, USA. Postflexion larvae of a gobiid used vision to remain within several meters of patch reefs during the day and on moonlit nights, but they drifted away from reefs during complete darkness. Furthermore, preflexion larvae did not aggregate around reefs. Other taxa were too rare to analyze or were more abundant away from reefs. There are indications from other regions that larvae may be closely associated with rocky or coral reefs throughout development (e.g. Powles 1977, Smith et al. 1987, Kingsford \& Choat 1989), but there was insufficient spatial resolution to determine how far offshore the assemblages extended.

A diversity of taxon-specific onshore/offshore larval distribution patterns is also apparent at larger spatial scales (reviewed by Leis 1991, also see Leis 1993, 1994). Larvae of some reef fishes are most abundant several kilometers off reefs while other taxa, primarily non-pelagic spawners, tend to be most abundant within a kilometer of reefs. The larval distributions suggested for some Gulf of California reef fishes are merely at the extreme nearshore end of the distribution spectrum.

The great variety of larval distribution patterns argues against the idea that offshore dispersal is generally necessary and beneficial for reef fishes (e.g. Barlow 1981). Larvae found offshore may require oceanic conditions to complete development, but offshore distribution could also be an accidental, even detrimental, consequence of reproductive mode and hatchling morphology, especially for pelagic spawners. The relative importance of selection and constraints for the evolution of traits affecting larval distributions is essentially unknown. The observation that larvae remaining near reefs are from the subset of taxa most likely to be able to influence their own distributions suggests that retention is beneficial to some species. The most obvious benefit is reduction of expatriation, but other benefits such as greater availability of food are also plausible.

Larval retention has important ecological and evolutionary implications. For example, there is an emerging consensus that population dynamics of reef fishes are largely controlled by the delivery of competent larvae to settlement sites (Doherty \& Williams 1988, Underwood \& Fairweather 1989, Doherty 1991, Sale 1991, Milicich et al. 1992, Meekan et al. 1993). If this is so, species with larval retention may have fundamentally different dynamics than other species because local processes, rather than large-scale oceanography, should determine the supply of settlers. Larval retention should also reduce gene flow between populations, so it has the potential to affect genetic population structure and processes such as adaptation, speciation, and extinction. These important issues await exploration. 
Acknowledgements. Field work was supported by the LernerGray Fund of the American Museum of Natural History (1989, 1990), the Sigma Xi Society $(1989,1990)$, the Graduate College of the University of Arizona (1990), and the Department of Ecology and Evolutionary Biology, University of Arizona. I am indebted to $C$. Henze, S. Schmidt, and students of D. Thomson's 1989 marine ecology course for their dedicated field assistance. H. G. Moser and W. Watson (Southwest Fisheries Science Center, NMFS, La Jolla) assisted me in examining CalCOFI collections. J. Bronstein, P. Hastings, R. Strauss, D. Thomson, and anonymous reviewers provided helpful comments. I was supported by the National Science Foundation (BSR-9113525; T. Pietsch, P. I.) while revising the manuscript. My appreciation is extended to all.

\section{LITERATURE CITED}

Ahlstrom, E. H. (1971). Kinds and abundance of fish larvae in the eastern tropical Pacific, based on collections made on EASTROPAC I. Fish. Bull. U.S. 69: 3-77

Ahlstrom, E. H. (1972). Kinds and abundance of fish larvae in the eastern tropical Pacific on the second multivessel EASTROPAC survey, and observations on the annual cycle of larval abundance. Fish. Bull. U.S. 70: 1153-1242

Barlow, G. W. (1981). Patterns of parental investment, dispersal and size among coral-reef fishes. Environ. Biol. Fish. 6: $65-85$

Barnett, A. M., Jahn, A. E., Sertic, P. D., Watson, W. (1984). Distribution of ichthyoplankton off San Onofre, California, and methods for sampling very shallow coastal waters. Fish. Bull. U.S. 82: 97-111

Black, K. P. (1993). The relative importance of local retention and inter-reef dispersal of neutrally buoyant material on coral reefs. Coral Reefs 12: 43-53

Black, K. P., Moran, P. J., Hammond, L. S. (1991). Numerical models show coral reefs can be self-seeding. Mar Ecol. Prog. Ser. 74: 1-11

Blaxter, J. H. S. (1986). Development of sense organs and behaviour of teleost larvae with special reference to feeding and predator avoidance. Trans. Am. Fish. Soc. 115: $98-114$

Brogan, M. W. (1992). Ecology of larval fishes around reefs in the Gulf of California, Mexico. Ph.D. dissertation, University of Arizona, Tucson

Brogan, M. W. (1994). Two methods of sampling fish larvae over reefs: a comparison from the Gulf of California. Mar. Biol. 118: 33-44

Clarke, T A. (1991). Larvae of nearshore fishes in oceanic waters near Oahu, Hawaii. NOAA Tech. Rep. NMFS 101 $1-19$

Cohen, D. M., Nielsen, J. G. (1978). Guide to the identification of genera of the fish order Ophidiiformes with a tentative classification of the order. NOAA Tech. Rep. NMFS Circ. 417: $1-72$

Colin, P. L., Clavijo, I. E. (1988). Spawning activity of fishes producing pelagic eggs on a shelf edge coral reef, southwestern Puerto Rico. Bull. mar. Sci. 43: 249-279

Conover, W. J. (1980). Practical nonparametric statistics, 2nd edn. John Wiley \& Sons, New York

Doherty, P. J. (1983). Diel, lunar and seasonal rhythms in the reproduction of two tropical damselfishes: Pomacentrus flavicauda and $P$. wardi. Mar. Biol. 75: 215-224

Doherty, P. J. (1991). Spatial and temporal patterns in recruitment. In: Sale, P. F. (ed.) The ecology of fishes on coral reefs. Academic Press, New York, p. 261-293
Doherty, P. J., Williams, D. McB. (1988). The replenishment of coral reef fish populations. Oceanogr. mar. Biol. 26: $487-551$

Doherty, P. J., Williams, D. McB., Sale, P. F. (1985). The adaptive significance of larval dispersal in coral reef fishes. Environ. Biol. Fish. 12: 81-90

Hunt von Herbing, [., Hunte, W. (1991). Spawning and recruitment of the bluehead wrasse Thalassoma bifasciatum in Barbados, West Indies. Mar. Ecol. Prog. Ser 72: $49-58$

Johannes, R. E. (1978). Reproductive strategies of coastal marine fishes in the tropics. Environ. Biol. Fish. 3: 65-84

Kingsford, M. J. (1990). Linear oceanographic features: a focus for research on recruitment processes. Aust. J. Ecol. 15: $391-401$

Kingsford, M. J., Choat, J. H. (1986). Influence of surface slicks on the distribution and onshore movements of small fish. Mar. Biol. 91: 161-171

Kingsford, M. J., Choat, J. H. (1989). Horizontal distribution patterns of presettlement reef fish: are they influenced by the proximity of reefs? Mar. Biol. 101: 285-297

Kingsford, M. J., Wolanski, E., Choat, J. H. (1991). Influence of tidally induced fronts and Langmuir circulations on distribution and movements of presettlement fishes around a coral reef. Mar. Biol. 109: 167-180

Kobayashi, D. R. (1989). Fine-scale distribution of larval fishes: patterns and processes adjacent to coral reefs in Kaneohe Bay, Hawaii. Mar. Biol. 100: 285-293

Leis, J. M. (1982). Nearshore distributional gradients of larval fish (15 taxa) and planktonic crustaceans (6 taxa) in Hawaii. Mar. Biol. 72: 89-97

Leis, J. M. (1983). Coral reef fish larvae (Labridae) in the East Pacific Barrier. Copeia 1983: 826-828

Leis, J. M. (1986a). Vertical and horizontal distribution of fish larvae near coral reefs at Lizard Island, Great Barrier Reef. Mar. Biol. 90: 505-516

Leis, J. M. (1986b). Epibenthic schooling by larvae of the clupeid fish Spratelloides gracilis. Jap. J. Ichthyol. 33: 67-69

Leis, J. M. (1991). The pelagic stage of reef fishes: the larval biology of coral reef fishes. In: Sale, P. F. (ed.) The ecology of fishes on coral reefs. Academic Press, New York, p. $183-230$

Leis, J. M. (1993). Larval fish assemblages near Indo-Pacific coral reefs. Bull mar. Sci. 53: 362-392

Leis, J. M. (1994). Coral Sea atoll lagoons; closed nurseries for the larvae of a few coral reef fishes. Bull. mar. Sci. 54: 206-227

Leis, J M., Goldman, B. (1984). A preliminary distributional study of fish larvae near a ribbon coral reef in the Great Barner Reef. Coral Reefs 2: 197-203

Leis, J. M., Goldman, B. (1987). Composition and distribution of larval fish assemblages in the Great Barrier Reef Lagoon, near Lizard Island, Australia. Aust. J. mar. Freshwat. Res 38: 211-223

Leis, J. M., Goldman, B., Reader, S. E. (1989). Epibenthic fish larvae in the Great Barrier Reef Lagoon near Lizard Island, Australia. Jap. J. Ichthyol. 35: 428-433

Leis, J. M., Rennis, D. S. (1983). The larvae of Indo-Pacific reef fishes. University of Hawaii Press, Honolulu

Leis, J. M., Trnski, T (1989). The larvae of Indo-Pacific shorefishes. University of Hawaii Press, Honolulu

Lobel, P. S., Robinson, A. R. (1986). Transport and entrapment of fish larvae by ocean mesoscale eddies and currents in Hawaiian waters. Deep Sea Res. 33: 483-500

Lobel, P. S., Robinson, A. R. (1988). Larval fishes and zooplankton in a cyclonic eddy in Hawaiian waters. J. Plankton. Res. 10: 1209-1223 
Maluf, L. Y (1983). The physical oceanography. In: Case, T. D., Cody, M. L. (eds.) lsland biogeography in the Sea of Cortez. University of California Press, Berkeley, p. 26-45

Marliave, J. B. (1986). Lack of planktonic dispersal of rocky intertıdal fish larvae. Trans. Am. Fish. Soc. 115: 149-154

Meekan, M. G., Milicich, M. J., Doherty, P. J. (1993). Larval production drives temporal patterns of larval supply and recruitment of a coral reef damselfish. Mar Ecol. Prog Ser. 93: 217-225

Milicich, M. J., Meekan, M. G., Doherty, P. J. (1992). Larval supply: a good predictor of recruitment in 3 species of reef fish (Pomacentridae). Mar. Ecol. Prog. Ser. 86: 153-166

Miller, T J., Crowder, L. B., Rice, J. A., Marschall, E. A (1988). Larval size and recruitment mechanisms in fishes toward a conceptual framework. Can. J. Fish. Aquat. Sci. 45: $1657-1670$

Moser, H. G., Ahlstrom, E. H., Kramer, D., Stevens, E. G (1973). Distribution and abundance of fish eggs and larvae in the Gulf of California. CalCOFl Report 17: 112-128

Moser, H. G., Richards, W. J., Cohen, D. M., Fahay, M. P., Kendall, A. W., Jr., Richardson, S. L. (eds.) (1984). Ontogeny and systematics of fishes. The American Society of Ichthyologists and Herpetologists, Lawrence, KS

Norcross, B. L., Shaw, R. F. (1984). Oceanic and estuarine transport of fish eggs and larvae: a review. Trans. A.m Fish. Soc. 113: 153-165

Pineda, J. (1991). Predictable upwelling and the shoreward transport of planktonic larvae by internal tidal bores. Science 253: $548-551$

Powles, H. (1977). Description of larval Jenkinsia lamprotaenia (Clupeidae, Dussumieriinae) and their distribution off Barbados, West Indies. Bull. mar. Sci. 27: 788-801

Richards, W. L. (1984). Kinds and abundances of fish larvae in the Caribbean Sea and adjacent areas. NOAA Tech. Rep. NMFS SSRF-776: 1-54

Robertson, D. R. (1991). The role of adult biology in the timing of spawning of tropical reef fishes. In: Sale, P. F. (ed.) The ecology of fishes on coral reefs. Academic Press, New York, p. 356-386

Ross, R. M. (1983). Annual, semilunar, and diel reproductive rhythms in the Hawaiian labrid Thalassoma duperrey Mar. Biol. 72: 311-318

This article was submitted to the editor
Sale, P. F (1991). Reef fish communities: open non-equilibrial systems. In: Sale, P. F. (ed.) The ecology of fishes on coral reefs. Academic Press, New York, p. 564-598

Shanks, A. L. (1988). Further support for the hypothesis that internal waves can cause shoreward transport of larval invertebrates and fish. Fish. Bull. U.S. 86: 703-714

Shapiro, D. Y., Hensley, D. A., Appeldoorn, R. S. (1988). Pelagic spawning and egg transport in coral-reef fishes: a skeptical overview. Environ. Biol. Fish. 22: 3-14

Smith, C. L., Tyler, J. C., Stillman, L. (1987). Inshore ichthyoplankton: a distinctive assemblage? Bull. mar. Sci. 41. $432-440$

Sokal, R. R., Rohlf, F. J. (1981). Biometry. The principles and practice of statistics in biological research, 2 nd edn. W. H. Freeman \& Co., New York

Springer, V. G. (1962). A review of the blenniid fishes of the genus Ophioblennius Gill. Copeia 1962: 426-433

Steffe, A. S. (1990). Epibenthic schooling by larvae of the atherinid fish Leptatherina presbyteroides: an effective mechanism for position maintenance. Jap. J. Ichthyol. 36: $488-491$

Stevens, E. G., Moser, H. G. (1982). Observations on the early life history of the mussel blenny, Hypsoblennius jenkinsi, and the bay blenny, Hypsoblennius gentilis, from specimens reared in the laboratory. CalCOFI Report 23: $269-275$

Thomson, D. A., Findley, L. T., Kerstitch, A. N. (1987). Reef fishes of the Sea of Cortez. The rocky-shore fishes of the Gulf of California. University of Arizona Press, Tucson

Thresher, R. E. (1984). Reproduction in reef fishes. T F. H. Publications, Neptune City, NJ

Underwood, A. J., Fairweather, P. G. (1989). Supply-side ecology and benthic marine assemblages. Trends Ecol Evol. 4: 16-19

Victor, B. C. (1987). Growth, dispersal, and identification of planktonic labrid and pomacentrid reef-fish larvae in the eastern Pacific Ocean. Mar. Biol. 95: 145-152

Young, P. C., Leis, J. M., Hausfeld, H. F. (1986). Seasonal and spatial distribution of fish larvae in waters over the North West Continental Shelf of Western Australia. Mar. Ecol. Prog. Ser. 31. 209-222

Manuscript first received: February 2, 1994

Revised version accepted: August 17, 1994 